\title{
Har kroppsvekt betydning for bentettheten hos eldre menn?
}

\author{
Trond Langerød ${ }^{1}$, Tore Tveitstul ${ }^{1}$, Haakon E. Meyer ${ }^{2}$ og Jan A. Falch ${ }^{3}$ \\ ${ }^{1}$ Det medisinske fakultet, Universitetet i Oslo \\ ${ }^{2}$ Divisjon for epidemiologi, Nasjonalt folkehelseinstitutt, Oslo \\ ${ }^{3}$ Benlaboratoriet, Medisinsk klinikk, Aker universitetssykehus $\mathrm{HF}$, Oslo \\ Adresse for korrespondanse: Tore Tveitstul, Ths. W. Schwartz gate 22b, Leilighet 0402, 1606 Fredrikstad \\ Telefon: 98642868 e-post: toretveitstul@hotmail.com
}

\begin{abstract}
SAMMENDRAG
Bakgrunn: Sammenhengen mellom kroppsvekt og benmineraltetthet (BMD) er velkjent, imidlertid finnes det færre data som omhandler denne sammenhengen hos menn. Formål: Vi ønsket å undersøke om mekanisk belastning ved å bære ens egen kroppsvekt har betydning for bentettheten. Materiale og metode: I forbindelse med Helseundersøkelsen i Oslo, målte vi BMD i en vektbærende skjelettregion (lårhalsen) og en ikke-vektbærende region (skallen) på 500 menn født i 1924-1925. Ved hjelp av ratioen: (BMD lårhals/ BMD skalle) så vi på de relative endringene i BMD lårhals i forhold til BMD skalle med økende kroppsvekt. Vi målte også fettandel, fettfri masse (lean mass) og høyde for å kunne se nærmere på virkningen andre aspekter ved kroppsstørrelsen har på BMD. BMD og kroppssammensetning ble målt med dobbel røntgen absorpsjonsmetri (DXA). Resultater: Kroppsvekt var signifikant korrelert med BMD i både lårhalsen $(\mathrm{r}=0,36)$ og i skallen $(\mathrm{r}=0,32) .13 \%$ av variabiliteten i BMD femur og $11 \%$ av variabiliteten i skallen ble forklart utfra kroppsvekt. BMD lårhals økte relativt mer i forhold til skallen med økende vekt, høyde og lean mass. Konklusjon: Våre data tyder på at mekanisk belastning ved å bære ens egen kroppsvekt har betydning for BMD hos eldre menn. Høyde og lean mass ga en tilsvarende relativ økning i lårhalsens BMD som kroppsvekt. En mulig forklaring på dette kan være at disse variablene har mekaniske (eller f.eks. metabolske) tilleggsfaktorer som enten virker synergistisk eller additivt på lårhalsens BMD.
\end{abstract}

\section{Langerød T, Tveitstul T, Meyer HE, Falch JA. Does body weight influence bone mineral density in older men? Nor J Epidemiol 2003; 13 (1): 185-191.}

\section{ENGLISH SUMMARY}

Background: The association between body weight and bone mineral density (BMD) is well established, but there remain less data concerning this association in men. Objective: The aim of our study was to determine the impact of mechanical forces due to carrying one's own weight on the BMD in older men. Material and methods: In connection to the Oslo Health Study, we measured BMD in a weight-bearing region (the proximal femur) and a non-weight-bearing region (the skull) in 500 men born in 1924-1925. Using the ratio: (BMD femur/ BMD skull) we studied the relative changes in BMD femur compared to the BMD skull due to increased body weight. We also measured fat mass, lean mass and height to study the impact of other aspects of body composition on BMD. BMD and body composition were measured by dual-energy X-ray absorptiometry (DXA). Results: Body weight was significantly correlated with both BMD femur $(r=0.36)$ and BMD skull $(r=0.32) .13 \%$ of the variability in BMD femur and $11 \%$ of $\mathrm{BMD}$ skull were explained by body weight. BMD femur increased relatively more compared with the skull with increasing weight, height and lean mass. Conclusion: Our data suggest that the mechanical forces due to carrying one's own weight are of importance for the BMD in older men. Height and lean mass produced a relative increase in BMD femur similar to the results for body weight. This may be explained by the fact that these measures imply additional mechanical or other (i.e. metabolic) factors which may work synergistically or additionally on the BMD of the femoral neck.

\section{INNLEDNING}

Mye av kunnskapen som foreligger om benmineraltetthet (bone mineral density, BMD), er kommet til veie gjennom kliniske studier rundt osteoporose. Målt BMD predikerer bruddrisiko, eksempelvis er det BMD i lårhalsen som best predikerer lårhalsbrudd (1). Den store utfordringen består likevel i å forklare hvorfor noen har lavere BMD enn andre - og dermed økt risiko for frakturer. Det vil derfor være av stor betydning å kunne kartlegge hvilke faktorer som påvirker BMD.

Det er kjent at BMD avtar med alder (2). I en tverrsnittsstudie av menn og kvinner mellom 65 og 74 år anslås det at omlag en tredjedel av dette tapet kan 
forklares utfra aldersassosiert vekttap (3). Videre eksisterer det en positiv assosiasjon mellom kroppsvekt og bentetthet $(4,5)$. Blant menn over 60 år er kroppsvekten den av de ulike målene på kroppsstørrelse som er blitt funnet å være den viktigste prediktor for BMD (6). Effekten av vekt og vektendring på BMD hos menn er imidlertid blitt funnet generelt mindre enn hos kvinner (7). Forklaringen på dette er uviss, men det virker sannsynlig at østrogenproduksjon i perifert fettvev hos postmenopausale kvinner spiller en viktig rolle. I en annen tverrsnittsstudie fant man også at fettmasse forklarer en større del av variabiliteten $i$ bentettheten hos kvinner enn hos menn. Dette er forenlig med at endogent østrogen spiller en viktigere rolle for preservasjon av benvev hos eldre kvinner enn hos eldre menn (8).

Kroppsvekt bestemmes i hovedsak av to hovedkomponenter, nemlig den totale fettmengden og fettfri masse (lean mass). Hvilken av disse to komponentene som er viktigst for BMD, varierer mellom de ulike skjelettregioner (4). I tillegg viser kroppen en unik evne til å "prioritere" høy BMD der det trengs mest, nemlig i vektbærende benvev. I en studie viste det seg at fysisk trening fører til reversibel lav BMD i ikkebelastede benregioner og høy bentetthet i vektbærende deler av skjelettet (9). En longitudinell studie som fulgte opp pasienter etter hoftebrudd, viste at BMD ble redusert $\mathrm{i}$ den friske lårhalsen, sannsynligvis som en følge av fysisk inaktivitet etter bruddet. Derimot ble det observert en økning i skalle-BMD hos de samme pasientene, mens BMD i armene forble den samme (10).

Det samme er blitt observert blant romfarere som pga. vektløsheten under romferdene har fått påvist økt BMD i ikke-vektbærende regioner (skalle, ribben og armer) og tilsvarende redusert BMD i vektbærende skjelettregioner (lumbalcolumna, bekken og underekstremiteter), med aller størst tap av bensubstans i proksimale femur (11).

Da det er sammenheng mellom kroppsvekt og BMD, ønsket vi å se nærmere på denne sammenhengen hos eldre menn. Vi ønsket å undersøke om mekanisk belastning ved å bære ens egen kroppsvekt har betydning for bentetthet. Dette ble undersøkt ved å måle BMD i vektbærende benvev (lårhalsen) samt ikke-vektbærende benvev (skallen) hos en gruppe eldre menn født i 1924 og 1925. Det ble også hos disse mennene målt mengde fett i kroppen, fettfri masse (lean mass) og høyde - for å se om andre aspekter ved kroppsvekten, enn den rent mekaniske belastningen $\mathrm{i}$ seg selv, har sterkere sammenheng med BMD.

\section{MATERIALE OG Metode}

\section{Populasjon}

Data benyttet i denne studien er samlet inn ved benlaboratoriet på Aker sykehus i perioden 1. september 2000 til 31. desember 2001, i forbindelse med tilleggsundersøkelsen vedrørende osteoporose tilknyttet Hel- seundersøkelsen i Oslo (HUBRO). HUBRO-undersøkelsen ble utført i 2000-2001 i et samarbeid mellom Statens helseundersøkelser (nå Nasjonalt folkehelseinstitutt), Universitetet i Oslo og Oslo kommune. Formålet med denne tilleggsundersøkelsen var blant annet å lete etter sammenhenger som kunne belyse hvorfor Oslo-folk får mer lårhalsbrudd enn andre.

Blant de som ble innkalt til HUBRO, var 1591 menn født i 1924/25 som tidligere hadde deltatt i Osloundersøkelsen i 1972/73. 949 (60\%) av disse møtte til HUBRO og fikk da også tilbud om å delta i tilleggsundersøkelsen. 620 (65\% av de frammøtte til HUBRO) av disse takket ja til tilbudet og deltok i tilleggsundersøkelsen ved Aker sykehus. Denne artikkelen er basert på data fra de første 469 mennene som ble undersøkt. Det ble under innsamlingen av data besluttet å øke antall menn som fikk tilbud om bentettetsmåling på Aker. Dette gjorde man ved å innkalle mannlige Oslo-beboere født i 1924/25 som ikke deltok i Oslo-undersøkelsen i 1972/73. Av disse inngår 31 i vår studie, slik at totalt 500 menn danner grunnlaget for vår artikkel.

\section{Måling av kroppssammensetning og benmineraltetthet}

Vekt (målt med undertøy og uten fottøy) og høyde (uten fottøy, med strak rygg mot vegg) ble målt ved benlaboratoriet på Aker sykehus. Deretter ble det ved hjelp av dobbel røntgenabsorpsjonsmetri (dual X-ray absorptiometry, DXA) med Lunar DPX-L (Lunar, Wisconsin, USA) utført målinger av helkropp samt måling av hofte. Vi valgte ut følgende variabler til bruk i analysen for å kunne teste hypotesen om mekanisk belastnings innvirkning på skjelettet: BMD lårhals $\left(\mathrm{g} / \mathrm{cm}^{2}\right)$, BMD skalle $\left(\mathrm{g} / \mathrm{cm}^{2}\right)$, veiet kroppsvekt $(\mathrm{kg})$, høyde $(\mathrm{cm})$, BMI $\left(\mathrm{kg} / \mathrm{m}^{2}\right)$, kroppsfett $(\mathrm{kg})$ (heretter omtalt som "fett i kg"), kroppsfett i \% av kroppsvekt (heretter omtalt som "fett \%"), fettfri masse (kg) (heretter omtalt som "lean mass"; dette er en verdi som beregnes ved å trekke vekten av knokler og fett fra total kroppsvekt) og fettfri masse i \% av kroppsvekt (heretter omtalt som "lean \%").

\section{Metodens reproduserbarhet}

Systematiske feilkilder ble vurdert og kontrollert ved daglig måling av en kjent standard. Reproduserbarheten for lårhalsmålinger utført av de ulike medarbeiderne ble vurdert. Variasjonskoeffisienten (CV\%) var henholdsvis 1,6, 2,5, 1,1, 1,7 og 3,3. Undersøkelse av reproduserbarheten for helkroppsmålingene ble ikke utført da dette ville påført deltagerne betydelig høyere stråledoser. Det henvises derfor til tidligere analyser utført med samme apparat i 1995. Fra helkroppsscanning ble det da målt total fettmasse (fett i kg), total fettprosent (fett \%) og lean mass med variasjonskoeffisenter på henholdsvis $1,9 \%, 1,9 \%$ og $1,5 \%$ (12).

\section{Vurdering av skallens BMD}

Vi var i utgangspunktet interessert i å sammenligne BMD i lårhals og i skalletak for å se om de mekaniske 
kreftene som utgjøres av å bære ens egen kroppsvekt har betydning for BMD. Bortsett fra skalletaket, er det naturlig å tenke seg at de fleste skjelettstrukturer i kroppen er påvirket av mekanisk belastning f.eks. i form av kroppsvekt eller drag fra muskelsener. Målingene av BMD i skalletaket kan derved anses som en "kontroll" til målingene fra den vektbærende lårhalsen. Standardanalysen av helkroppsmåling med DXA gir informasjon om BMD i hele hodet (fra rett under haka og til issen) og er ikke spesifikk for skalletaket. Det er imidlertid flere teoretiske problemer ved å bruke hele hodets BMD i stedet for skalletakets BMD ved vår problemstilling. Ved å bruke hele hodet, vil man blant annet få med områder i nakke og bakre skalle som har feste for muskulatur og således vil være påvirket av mekanisk belastning. I tillegg vil tannfyllinger og fravær av tenner kunne påvirke resultatet $(13,14)$.

Vi utførte derfor en pilotstudie der vi reanalyserte målingene for de siste 20 pasientene slik at verdier for skalletak ble tilgjengelige. Skalletaket ble definert som området over den horisontale linjen gjennom nedre orbitarand (margo infraorbitalis, se figur 1). Verdier for hele skallen og verdier for skalletaket ble sammenlignet. Korrelasjonskoeffisienten (r) mellom BMD i skalletaket og BMD i hele hodet var 0,91 ( $\mathrm{p}<0,001)$. Denne korrelasjonen er så høy at vi i denne artikkelen har valgt å benytte de ferdig beregnede verdiene for hele hodet som et estimat for BMD i skalletaket. For mer utførlig beskrivelse av pilotprosjektet henvises det til forfatternes studentoppgave "Har kroppsvekt betydning for bentettheten hos eldre menn" (15).

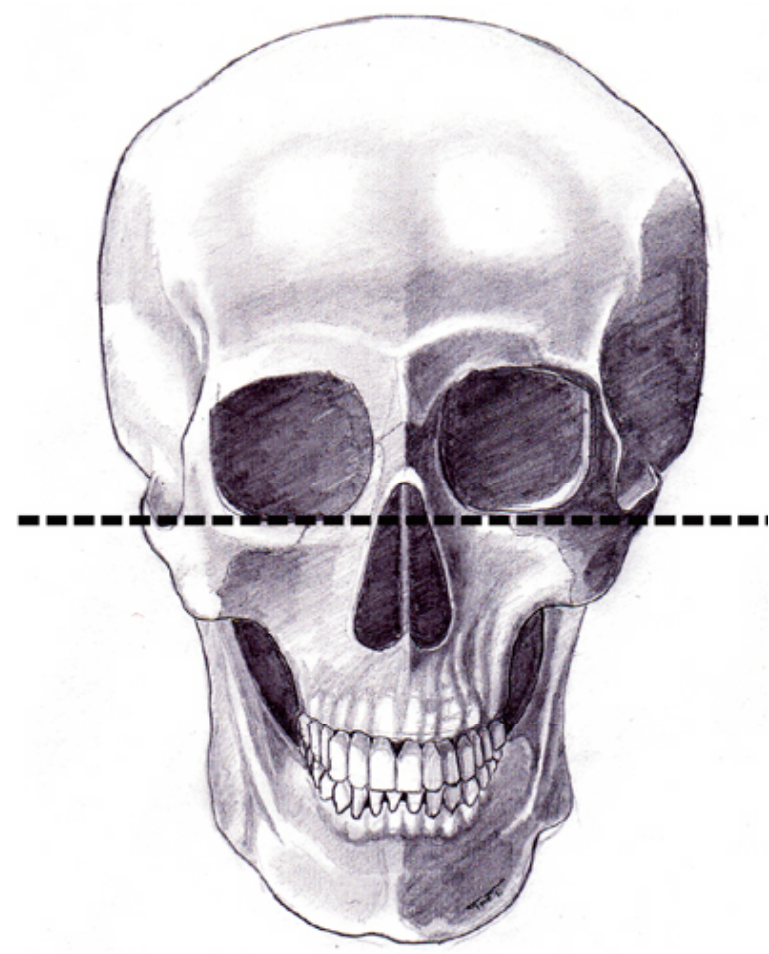

Figur 1. Skalletaket blir her definert som alle beinete strukturer over den horisontale linjen gjennom nedre orbitarand.

\section{Statistiske metoder}

Data ble analysert ved hjelp av statistikkfunksjonene i Excel. Det ble konstruert spredningsdiagrammer og beregnet Pearsons korrelasjonskoeffisient (r) og determinasjonskoeffisient $\left(r^{2}\right)$ for sammenhengen mellom kroppsvekt og BMD i lårhals og skalle. Dernest ble de samme statistiske operasjoner utført med de andre målene for kroppsstørrelse (høyde, BMI, fett i kg, fett $\%$, lean mass, lean \%). Alle signifikansverdier ble beregnet på bakgrunn av to-sidede tester.

Forholdet mellom ratioen (BMD lårhals)/(BMD skalle) og de ulike målene for kroppsstørrelse ble underlagt enkel lineær regresjonsanalyse. Stigningstall og signifikansverdier for regresjonslinjene ble beregnet. Denne analysen ble gjort for å se om det er økning i BMD på mekanisk belastet benvev i forhold til skallen når de ulike mål for kroppstørrelse øker. Denne ratioen har også vært brukt i forskningssammenheng tidligere for å beskrive endring av BMD i de to ulike regionene ved fysisk aktivitet (16).

\section{RESUltater}

Gjennomsnittet av lårhalsens BMD $\left(0,89 \mathrm{~g} / \mathrm{cm}^{2}, 95 \%\right.$ konfidensintervall: $0,88-0,91)$ var signifikant lavere enn skallens BMD $\left(2,05 \mathrm{~g} / \mathrm{cm}^{2}, 95 \%\right.$ konfidensintervall: 2,03-2,07). Deskriptive data for de ulike målene for kroppsstørrelse finnes i tabell 1. Den gjennomsnittlige kroppsvekten var på $80,1 \mathrm{~kg}$, mens gjennomsnittlig høyde var på $175,9 \mathrm{~cm}$. Gjennomsnittlig BMI for populasjonen var $25,9 \mathrm{~kg} / \mathrm{m}^{2}$.

Tabell 1. Målinger av kroppssammensetning, angitt med gjennomsnitt og standardavvik (SD) samt minimums- og maksimumsverdier. Kroppsvekt og høyde er målt manuelt, og BMI er utledet fra disse målingene. De resterende variablene er målt ved hjelp av DXA. $n=500$.

\begin{tabular}{lcrrc}
\hline & Gjennomsnitt & SD & Min & Max \\
\hline Kroppsvekt (kg) & 80,1 & 10,5 & 51,0 & 114,0 \\
Høyde (cm) & 175,9 & 6,0 & 157,0 & 197,0 \\
Body mass index & & & & \\
$($ BMI, kg/m²) & 25,9 & 2,9 & 16,6 & 35,2 \\
Fett $(\mathrm{kg})$ & 21,8 & 6,0 & 6,6 & 40,8 \\
Fett \% & 26,9 & 5,0 & 10,8 & 41,1 \\
Lean mass $(\mathrm{kg})$ & 55,5 & 5,9 & 36,2 & 74,2 \\
Lean \% & 69,6 & 5,0 & 55,1 & 87,0 \\
\hline
\end{tabular}

Korrelasjoner mellom de ulike mål for kroppsstørrelse finnes i tabell 2. De fleste mål for kroppsstørrelse var signifikant korrelert til hverandre, bortsett fra høyde/BMI, høyde/fett \% og lean mass/lean \%. Korrelasjonene der lean \% inngikk, var negative. Korrelasjonen mellom $\mathrm{BMD}$ i lårhals og $\mathrm{BMD}$ i skallen var $0,41(\mathrm{p}<0,001)$.

I tabell 3 er det beregnet Pearsons korrelasjonskoeffisient for sammenhengen mellom de ulike målene 
Tabell 2. Korrelasjon mellom de ulike mål for kroppsstørrelse, beregnet ved Pearsons korrelasjonskoeffisient (r). $n=500$.

\begin{tabular}{lccclcl}
\hline & Høyde & BMI & Fett i kg & Fett \% & Lean mass & Lean $\%$ \\
\hline Kroppsvekt & $0,52^{* * *}$ & $0,85^{* * *}$ & $0,84^{* * *}$ & $0,56^{* * *}$ & $0,84^{* * *}$ & $-0,59^{* * *}$ \\
Høyde & & $-0,01$ & $0,29^{* * *}$ & 0,06 & $0,58^{* * *}$ & $-0,09^{*}$ \\
BMI & & & $0,81^{* * *}$ & $0,63^{* * *}$ & $0,62^{* * *}$ & $-0,63^{* * *}$ \\
Fett i kg & & & & $0,91^{* * *}$ & $0,46^{* * *}$ & $-0,87^{* * *}$ \\
Fett \% & & & & & $0,10^{*}$ & $-0,91^{* * *}$ \\
Lean mass & & & & & & $-0,07$ \\
\hline$* p<0,05 ; * * p<01 ; * * * p<0,001$ & & & & &
\end{tabular}

${ }^{*} \mathrm{p}<0,05 ; * * \mathrm{p}<0,01 ; * * * \mathrm{p}<0,001$

for kroppsstørrelse og BMD. Alle korrelasjonene er signifikante $(\mathrm{p}<0,05)$. Alle korrelasjonene er positive, bortsett fra korrelasjonene der lean \% inngikk. Best korrelasjon var det mellom kroppsvekt og BMD i lårhals og mellom lean mass og BMD $i$ lårhals (for begge er $\mathrm{r}=0,36)$. Det er også beregnet determinasjonskoeffisient $\left(\mathrm{r}^{2}\right)$, som angir at maksimalt $13 \%$ av individuelle forskjeller i BMD kan forklares av forskjeller i kroppssammensetning.

Gjennomsnitt for ratioen (BMD lårhals)/(BMD skalle) var 0,44 med et standardavvik på 0,07 . I tabell 4 er det ved hjelp av enkel lineær regresjonsanalyse beregnet stigningstall til regresjonslinjen for sammenhengen mellom ratioen (BMD lårhals)/(BMD skalle) og målene for kroppsstørrelse. Målene for kroppsstørrelse er oppgitt per standardavvik økning for det enkelte kroppsmål for lettere å kunne sammenligne stigningstallene. Signifikante resultater ble funnet for vekt $(\mathrm{p}<0,01)$, høyde $(\mathrm{p}<0,01)$ og lean mass $(\mathrm{p}<0,001)$. Som man kan se av de betydelig overlappende konfidensintervallene, er disse resultatene for vekt, høyde og lean mass ikke signifikant forskjellig fra hverandre.

\section{DISKUSJON}

I denne studien av 500 menn født i 1924 og 1925 fant vi at BMD femur øker forholdsvis mer med økende vekt, høyde og lean mass enn hva tilfellet er for BMD skalle.

Tabell 3. Korrelasjoner mellom mål for kroppsstørrelse og BMD, angitt ved Pearsons korrelasjonskoeffisient (r) og determinasjonskoeffisienten $\left(\mathrm{r}^{2}\right)$.

\begin{tabular}{lcccccc}
\hline & \multicolumn{2}{c}{ BMD lårhals } & & \multicolumn{2}{c}{ BMD skalle } \\
\cline { 2 - 3 } \cline { 5 - 6 } & $\mathrm{r}$ & $\left(\mathrm{r}^{2}\right)$ & & $\mathrm{r}$ & $\left(\mathrm{r}^{2}\right)$ \\
\hline Kroppsvekt & 0,36 & $(0,13)^{* * *}$ & & 0,32 & $(0,11)^{* * *}$ \\
Høyde & 0,26 & $(0,07)^{* * *}$ & & 0,15 & $(0,02)^{* * *}$ \\
BMI & 0,27 & $(0,07)^{* * *}$ & & 0,28 & $(0,08)^{* * *}$ \\
Fett kg & 0,23 & $(0,05)^{* * *}$ & & 0,26 & $(0,07)^{* * *}$ \\
Fett \% & 0,09 & $(0,01)^{*}$ & & 0,15 & $(0,02)^{* *}$ \\
Lean mass & 0,36 & $(0,13)^{* * *}$ & & 0,24 & $(0,06)^{* * *}$ \\
Lean \% & $-0,14$ & $(0,02)^{* *}$ & & $-0,23$ & $(0,05)^{* * *}$ \\
\hline
\end{tabular}

${ }^{*} \mathrm{p}<0,05, * * \mathrm{p}<0,01, * * * \mathrm{p}<0,001$
Vi fant at gjennomsnittlig BMD er langt høyere i skallen enn i lårhalsen. Dette er resultater som er forenlige med andres målinger gjort av de samme skjelettregionene (16). Vi var primært ikke ute etter å sammenligne absoluttverdier for BMD i vektbærende og ikke-vektbærende knokler, men å se på hvilken sammenheng ulike mål for kroppsstørrelse har med BMD.

\section{Sammenhenger mellom de ulike mål for kroppsstorrelse}

Korrelasjonene mellom de ulike målene for kroppsstørrelse viser stort sett signifikante, positive verdier. Dette kan tyde på at de ulike målene samvarierer og til dels er avhengig av hverandre. De to ikke-signifikante verdiene for høyde, samt at høyde har den laveste korrelasjonen med kroppsvekt og den laveste korrelasjonen med fettmasse (fett i kg), kan tyde på at høyde er en mer isolert størrelse, som er mer uavhengig av de andre målene for kroppsstørrelse. De positive, signifikante korrelasjonene med de ulike målene for kroppsstørrelse og lean mass indikerer en klar sammenheng mellom lean mass og kroppsstørrelse. Da samtlige korrelasjoner til lean \% er negative, kan dette tyde på at økende kroppmasse innebærer relativt sett mer opphopning av fett enn av lean mass (hovedsaklig muskler og innvoller). Dette kan delvis bero på aldersfysiologiske fenomener som kan være at eldre menn har lettere for å legge på seg fett enn å bygge opp muskler, eller sammenhengen mellom økt kroppsstørrelse og usunn livsstil (inaktivitet og usunt kosthold).

Tabell 4. Stigningstall $(\mathrm{x} 1000)$ for de ulike målene for kroppsstørrelse mot ratioen (BMD lårhals)/(BMD skalle) (enkel lineær regresjonsanalyse). Målene for kroppsstørrelse er oppgitt per standardavvik økning for det enkelte kroppsmål. 95\% konfidensintervall for stigningstallene er oppgitt.

\begin{tabular}{lcc}
\hline & $\begin{array}{c}\text { Ratio (BMD lårhals)/ } \\
\text { (BMD skalle) }\end{array}$ & p-verdi \\
\hline Vekt & $8,3(2-14)$ & 0,007 \\
Høyde & $10,5(4-16)$ & 0,001 \\
BMI & $3,4(\div 3-9)$ & 0,279 \\
Fett i kg & $2,8(\div 3-9)$ & 0,363 \\
Fett \% & $\div 0,9(\div 7-5)$ & 0,769 \\
Lean mass & $11,5(5-17)$ & 0,000 \\
Lean \% & $1,1(\div 5-7)$ & 0,736 \\
\hline
\end{tabular}




\section{Sammenheng mellom BMD lårhals og BMD skalle}

BMD lårhals hadde en moderat, men signifikant positiv korrelasjon med BMD skalle $(r=0,41)$. En del av denne sammenhengen kan sannsynligvis forklares utfra genetikk. En kan tenke seg at genetiske faktorer gjør at noen har generelt høy BMD i hele skjelettet mens andre har lav BMD. Det er anslått at så mye som $70-80 \%$ av en persons "Peak bone mass" (den høyeste verdien for BMD et individ oppnår) er genetisk bestemt (17). Kanskje kan korrelasjonen delvis også forklares ved andre faktorer som påvirker begge skjelettregioner, for eksempel hormoner produsert i fettvev eller tobakksrøyking.

\section{Sammenhenger mellom målene for kroppsstorrelse og BMD}

Når det gjelder sammenhenger mellom ulike kroppsmål og BMD i lårhals og skalle, fant vi best korrelasjon mellom kroppsvekt og BMD. Korrelasjonskoeffisientene indikerer en noe høyere korrelasjon for kroppsvekt med lårhals enn med skalle. $13 \%$ av variabiliteten i lårhalsens BMD er forklart av kroppsvekten, mens $11 \%$ av variabiliteten i skallens BMD er forklart av kroppsvekten. Dette antyder en effekt av mekanisk belastning på lårhalsen med økende kroppsvekt. Lean mass viser også samme trend, med like god korrelasjon med BMD lårhals. Dette kan bero på at lean mass utgjør en så stor del av kroppsvekten (i vår undersøkelse gjennomsnittlig $69,6 \%$ av total kroppsvekt). $13 \%$ av variabiliteten $\mathrm{i}$ lårhalsens $\mathrm{BMD}$ er forklart av lean mass, mot $6 \%$ av variabiliteten i skallens BMD. Dette antyder også en sammenheng mellom mekanisk belastning og BMD. Høyde følger samme tendens: $7 \%$ av variabiliteten i lårhalsens BMD er forklart av høyden, mot $2 \%$ av variabiliteten i skallens BMD.

Fett $\mathrm{i} \mathrm{kg}$ har en noe svakere positiv korrelasjon med BMD i lårhals enn det kroppsvekt og lean mass har. Dette kan bero på at andelen fett av total kroppsvekt er mindre (i vår undersøkelse gjennomsnittlig $26,9 \%)$ enn andelen lean mass. Således vil ikke den mekaniske belastningen som fettet utgjør være så stor. Det kan virke som om det er den totale vekt i kilo som er viktigst for korrelasjon med lårhalsens $\mathrm{BMD}$, ikke hva kiloene "inneholder". Trenden for korrelasjonen mellom fett $\mathrm{i} \mathrm{kg}$ og verdiene for BMD synes litt annerledes: $5 \%$ av variabiliteten i lårhalsens BMD er forklart av fett i $\mathrm{kg}$ mens $7 \%$ av variabiliteten av skallens BMD er forklart av fett i kg. Dette kan tyde på at det kan være andre faktorer enn den mekaniske belastningen som utgjøres av vekten av fett som påvirker BMD, for eksempel hormonproduksjon i fettvev. Dette er vist å være av betydning hos kvinner, men det er uvisst hvor mye dette har å si for BMD hos menn (7). Man vet fra tidligere studier at det meste av østrogenet hos menn kommer fra konvertering av androgener i fettvev (18-20). Dette antyder at menn med mer fettvev produserer mer østrogener og har mindre bentap med alderen (21). Tendensen til høyere korrelasjon mellom skallen og fett \% er den samme som for fett i kg.

Vekt er et enkelt mål for kroppsstørrelse og synes som den beste markøren for BMD i begge de undersøkte knokkeldeler. Som nevnt er kroppsvekten den av de ulike målene på kroppsstørrelse som av andre er blitt funnet å være den viktigste prediktor for BMD hos menn over 60 år (6).

\section{Sammenhenger mellom mål for kroppsstorrelse og ratioen (BMD lårhals)/(BMD skalle)}

Vi fant at BMD lårhals øker forholdsmessig mer enn BMD skalle med økende kroppsvekt. Dette tyder på at den mekaniske belastningen kroppsvekten utgjør har betydning for BMD. BMD lårhals øker også i forhold til BMD skalle med økende lean mass. Dette er den samme tendensen som vi ser for kroppsvekten og ikke uventet, da lean mass utgjør størstedelen av total kroppsvekt og vil være viktig for mekanisk belastning på lårhalsen. I tillegg til den sterke korrelasjonen lean mass har med kroppsvekt $(\mathrm{r}=0,84)$, vil også økende lean mass sannsynligvis bety økende mengde muskler, som igjen vil kunne gi økt drag i muskelfester som vil forsterke den mekaniske belastningen på lårhalsen. For lean mass synes det altså å være en tilleggsfaktor til den rent "passive" mekaniske belastningen som den store andelen av kroppsvekten utgjør. Dessuten kan en jo anta at økt muskelmasse skyldes et høyere fysisk aktivitetsnivå som i seg selv stimulerer til høy BMD (16).

Økende høyde fører også til en økning av BMD lårhals i forhold til BMD skalle, noe som sannsynligvis delvis kan forklares ved at økt høyde henger sammen med økt kroppsvekt som gir økt mekanisk belastning på lårhals og dermed høyere BMD. Dette er trolig bare deler av forklaringen, da høyden bare er moderat korrelert med kroppsvekten $(\mathrm{r}=0,52)$. En alternativ hypotese er at lange menn også har lengre lårhals. De mekaniske forholdene i lårhalsen kan da endres noe, slik at man får et større moment ved belastning av femurhodet, og dermed også relativt sett større mekanisk belastning av lårhals enn hva kroppsvekten skulle tilsi. Således vil lange og tynne menn kunne få relativt stor mekanisk belastning av lårhalsen selv om kroppsvekten er beskjeden. Dette kan være forenlig med våre data: Høyden var den variabelen for kroppsstørrelse som ga lavest positiv korrelasjon med kroppsvekt.

Det faktum at økning av fett i kg ikke fører til signifikant endring av forholdet mellom BMD lårhals og BMD skalle, kan igjen tyde på at det ikke er den mekaniske belastningen ved fettet som er avgjørende for BMD, men eventuelt andre egenskaper ved fettvevet (som for eksempel dets evne til hormonproduksjon). Videre kan det tyde på at effekten av disse andre egenskapene er svært lik på BMD skalle og BMD lårhals. Fettet spiller nok sannsynligvis en rolle for den mekaniske belastningen, men da vekten av fettet som tidligere nevnt utgjør en svært liten del av den totale 
kroppsvekten, kommer betydningen av dette ikke frem.

\section{Skjelettstorrelsens innvirkning på BMD}

Vi ser altså at det er de absolutte mål for kroppsstørrelse (kroppsvekt, høyde og lean mass) som gir den største relative økningen i lårhalsens BMD. Dette kan, som nevnt, sannsynligvis forklares utfra økt mekanisk belastning på vektbærende deler av skjelettet. Et generelt problem ved sammenlikning av BMD (areal mineral tetthet), er at verdiene påvirkes og forstyrres av skjelettstørrelsen (22). BMD-verdier er større hos mennesker med større skjelett, for eksempel afroamerikanere (23), fordi justeringen for det scannede areal $\left(\mathrm{i} \mathrm{g} / \mathrm{cm}^{2}\right)$ ikke fullstendig korrigerer for det faktum at vide (2dimensjonal bredde) knokler er tykkere (3-dimensjonal dybde). I vår studie har vi primært sammenliknet BMD-verdier for skalle og lårhals innenfor det enkelte individ (vha. ratioen BMD lårhals/BMD skalle). Da en må anta at størrelsen på knokler fra ulike lokalisasjoner innenfor ett individ er proporsjonale, er det lite trolig at våre signifikante resultater skyldes confounding på bakgrunn av kroppsstørrelse.

\section{Frafall}

Som nevnt under "Materiale og metode", deltok under halvparten av de innkalte ved tilleggsundersøkelsen på Aker. Vi kan ikke utelukke at vår undersøkelse tar for seg en gruppe menn som er friskere og mer aktive enn gjennomsnittet for den aktuelle aldersgruppe. Det er imidlertid ikke innlysende at dette skulle få vesentlig betydning for de assosiasjoner som beskrives i denne studien.

\section{Sammenheng mellom kroppsvekt og frakturrisko}

En diskusjon rundt frakturrisiko og osteoporose er ingen del av vår problemstilling; likevel har vi valgt å ta med noen enkle beregninger og kommentarer her. Oslo ligger på verdenstoppen i forekomst av lårhals- brudd, med en insidens på 78/10000 for menn i alderen 75-79 år (24). Måling av BMD i lårhalsen har vist seg som en god prediktor for lårhalsbrudd. En metaanalyse konkluderte med at den relative risikoen for å brekke lårhalsen for kvinner øker med 2,6 for hvert standardavvik BMD lårhals synker (1). Det er få lignende studier for menn, men den prediktive verdien av målinger av BMD ser ut til å være den samme for begge kjønn (25). Vi utførte derfor lineær regresjonsanalyse på sammenhengen mellom mål for kroppsstørrelse (kroppsvekt og BMI) og BMD lårhals. Deretter samholdt vi stigningstallene fra disse analysene med opplysningene fra metaanalysen nevnt ovenfor. Det viste seg da at en nedgang i total kroppsvekt på 29,2 $\mathrm{kg}$ eller en nedgang i BMI på $11,1 \mathrm{~kg} / \mathrm{m}^{2}$ ga en økning i relativ risiko for lårhalsbrudd på 2,6. Dersom vi ser bort fra andre risikofaktorer, vil f.eks. en 75 år gammel mann på $60 \mathrm{~kg}$ ha $160 \%$ høyere risiko for et lårhalsbrudd sammenlignet med en på $90 \mathrm{~kg}$.

\section{KONKLUSJON}

Vår undersøkelse tyder på at mekanisk belastning ved å bære ens egen kroppsvekt har betydning for BMD i vektbærende skjelettdeler hos eldre menn. Økning i total kroppsvekt gir i vår undersøkelse signifikant økning i BMD lårhals i forhold til BMD skalle. En tilsvarende relativ økning i BMD lårhals ser vi også for økende høyde og lean mass. Dette kan bero på at disse variablene har mekaniske tilleggsfaktorer i tillegg til den "passive" belastningen av kroppsvekten. Slike tilleggsfaktorer kan være drag av muskulatur på knokler og endrede kraftforhold som følge av endret lengde på lårhalsen.

\section{ACKNOWLEDGEMENT}

Datainnsamlingen ble utført som en del av helseundersøkelsen i Oslo 2000-2001 i samarbeid med Statens helseundersøkelser - nå Nasjonalt Folkehelseinstitutt.

\section{REFERANSER}

1. Marshall D, Johnell O, Wedel H. Meta-analysis og how well measures of bone mineral density predict occurrence of osteoporotic fractures. BMJ 1996; 312: 1254-1259.

2. Falch JA, Meyer HE. Beinmineraltetthet målt med dobbel røntgenabsorpsjonsmetri. Et referansemateriale fra Oslo. Tidsskr Nor Lcegeforen 1996; 19: 2299-2302.

3. May H, Murphy S, Khaw KT. Age-associated bone loss in men and women and its relationship to weight. Age Ageing 1994; 23: 235-240.

4. Nguyen TV, Howard GM, Kelly PJ, Eisman JA. Bone mass, lean mass, and fat mass: same genes or same environment? Am J Epidemiol 1998; 147: 3-16.

5. Holbrook TL, Barrett-Connor E. The association of lifetime weight and weight control patterns with bone mineral density in an adult community. Bone Miner 1993; 20: 141-149.

6. Orwoll ES, Bevan L, Phipps KR. Determinants of bone mineral density in older men. Osteoporosis Int 2000; 11: $815-821$. 
7. Felson DT, Zhang Y, Hannan MT, Anderson JJ. Effects of weight and body mass index on bone mineral density in men and women: the Framingham study. J Bone Miner Res 1993; 8: 567-573.

8. Edelstein SL, Barrett-Connor E. Relation between body size and bone mineral density in elderly men and women. Am J Epidemiol 1993; 3: 160-169.

9. Magnusson H, Linden C, Karlsson C, Obrant KJ, Karlsson MK. Exercise may induce reversible low bone mass in unloaded regions and high bone mass in weight-loaded regions. Osteoporosis Int 2001; 12: 950-955.

10. Magnusson HI, Linden C, Obrant KJ, Johnell O, Karlsson MK. Bone mass changes in weight-loaded and unloaded skeletal regions following a fracture of the hip. Calcif Tissue Int 2001; 69: 78-83.

11. Oganov VS, Grigor'ev AI, Voronin LI, Rakhmanow AS, Bakulin AV, Schneider VS, LeBlanc AD. Bone mineral density in cosmonauts after flights lasting 4.5-6 months on the Mir orbital station. Aviakosm Ekolog Med 1992; 26: 20-24.

12. Rishaug U, Birkeland KI, Falch JA, Vaaler S. Bone mass in non-insulin-dependent diabetes mellitus. Scand J Clin Lab Invest 1995; 55: 257-262.

13. von Wowern N. Bone mineral content of mandibles: normal reference values - rate of age-related bone loss. Calcif Tissue Int 1988; 43: 193-198.

14. von Wowern N. In vivo measurement of bone mineral content of mandibles by dual-photon absorptiometry. Scand J Dent Res 1985; 93: 162-168.

15. Tveitstul T, Langerød T. Har kroppsvekt betydning for bentettheten hos eldre menn? Studentoppgave ved Det medisinske fakultet, Universitetet i Oslo, 2002.

16. Karlsson MK, Hasserius R, Obrant KJ. Bone mineral density in athletes during and after career: a comparison between loaded and unloaded skeletal regions. Calcif Tissue Int 1996; 59: 245-248.

17. Falch JA, Meyer HE. Osteoporose og brudd i Norge. Forekomst og risikofaktorer. Tidsskr Nor Lageforen 1998; 118: 568-572.

18. Schindler AE, Ebert A, Friedrich E. Conversion of androstendione to estrone by human fat tissue. $J$ Clin Endocrinol Metab 1972; 35: 627-630.

19. Kley HK, Deselaers T, Peerenboom H, et al. Enhanced conversion of androstendione to estrone in obese males. J Clin Endocrinol Metab 1980; 51: 1128-1132.

20. Grodin JM, Siiteri PK, MacDonald PC. Source of estrogen production in postmenopausal women. $J$ Clin Endocrinol Metab 1973; 36: 207-214.

21. Bell HN, Epstein S, Green A, et al. Evidence for alteration of the vitamin D-endocrine system in obese objects. J Clin Invest 1985; 76: 370-373.

22. Seeman E. Growth in bone mass and size: are racial and gender differences in bone mineral density more apparent than real? J Clin Endocrinol Metab 1998; 83: 1414-1419.

23. Trotter M, Broman GE, Peterson RR. Densities of bones of white and negro skeletons. J Bone Joint Surg Am 1960; 42: 50-58.

24. Falch JA, Kaastad TS, Bohler G, Espeland J, Sundsvold OJ. Secular increase and geographical differences in hip fracture incidence in Norway. Bone 1993; 14: 643-645.

25. Nguyen T, Sambrook P, Kelly P, et al. Prediction of osteoporotic fractures by postural instability and bone density. $B M J$ 1993; 307: 1111-1115. 